\title{
Electrical coupling in the retina ganglion cell layer increases the dynamic range
}

\author{
Cesar A Celis ${ }^{*}$, Rodrigo Publio, Antonio C Roque \\ From The Twenty Third Annual Computational Neuroscience Meeting: CNS*2014 \\ Québec City, Canada. 26-31 July 2014
}

The vertebrates deal with visual stimuli with a broad range of intensity values. To enable these organisms to respond to this wide range of intensities there must be some mechanism capable of compressing the sensory signals at the retina [1]. It has been hypothesized that the wide dynamic range of the retina is due to electrical coupling of retinal ganglion cells (GCs) at the retina's output layer [1-3]. The dynamic range of a network of neurons can be defined as the range of input stimuli values for which the network responds before saturation. In this work we constructed a biologically plausible model of the ganglion cell layer of the salamander retina and submitted it to simulated input stimuli. The GCs are connected via gap junctions and different values of the average connectivity were used to evaluate the effect of electrical coupling on the dynamic range of the network. We used the conductance-based model of the tiger salamander GC of Fohlmeister and Miller [4]. This is a single-compartment model containing the following voltage-dependent membrane conductances: sodium, calcium, A-type potassium, calcium activated potassium, and delayed rectifier potassium. A 20x20 square lattice was built with one GC in each node. Each GC in the network is randomly connected by electrical synapses with its nearest neighbors, with the average number of coupled neighbors being $k=0,2$ or 4 . The network was stimulated by injecting in each cell an excitatory postsynaptic current with synaptic conductance modeled by an alpha function with decay time of $400 \mathrm{~ms}$. The reversal potential of the synaptic current was set as $1.5 \mathrm{mV}$. The simulations were run using the NEURON simulator. The response of the network was taken as the total number of spikes during $1 \mathrm{sec}$ of stimulation. Based on the F-I curves for the network we calculated the

\footnotetext{
* Correspondence: cesarcelis@usp.br

Department of Physics, FFCLRP, University of Sao Paulo, Ribeirao Preto, Sao
} Paulo, Brazil dynamic range (in decibels) for each average connectivity index $k$. The results (Figure 1) show that electrical coupling enhances the dynamic range of the GC network. This suggests that GC coupling via electrical

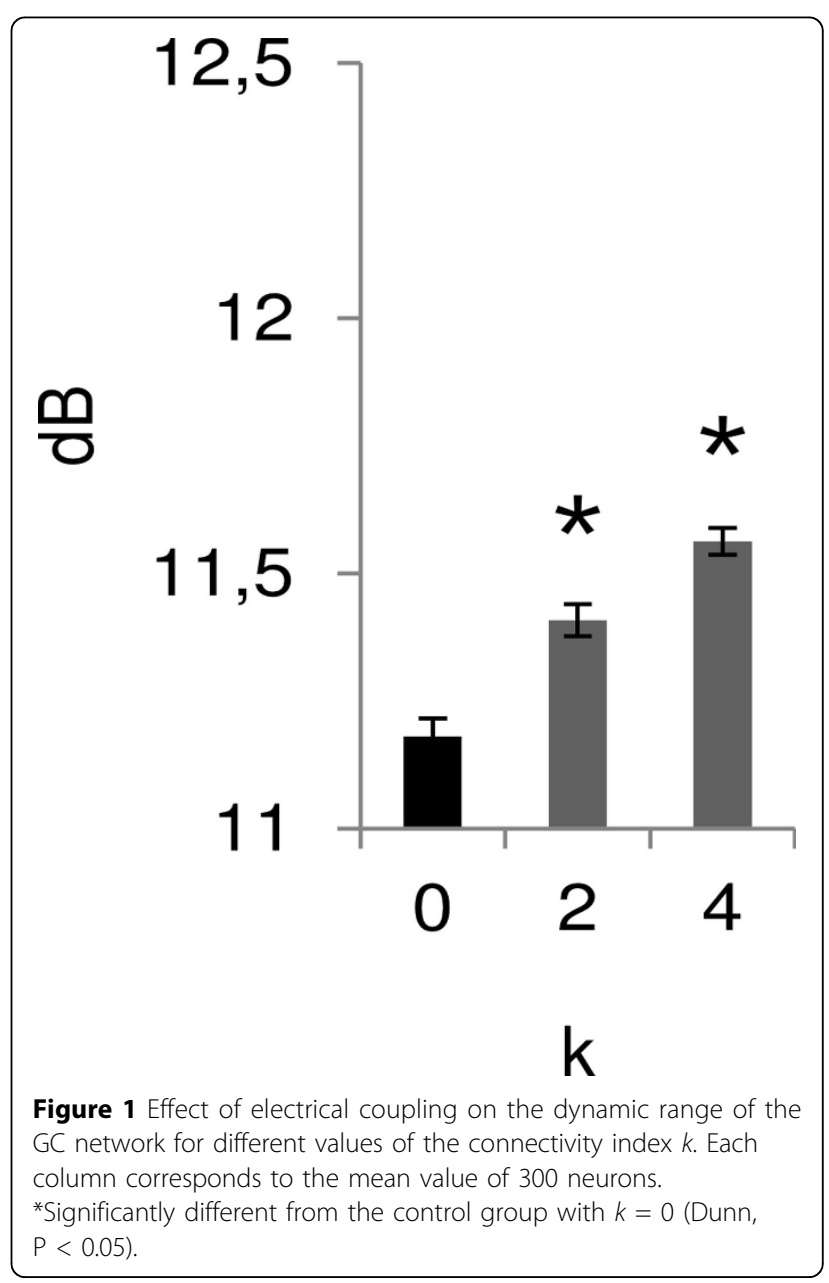


synapses may be involved in the mechanism that endows the vertebrate retina with its large dynamic range.

\section{Acknowledgments}

CC is supported by a CAPES scholarship, RP is supported by a CNPq

scholarship and ACR is the recipient of a CNPq research grant.

Published: 21 July 2014

\section{References}

1. Copelli M, Oliveira RF, Roque AC, Kinouchi O: Signal compression in the sensory periphery. Neurocomput 2005, 65:691-696.

2. Copelli M, Roque AC, Oliveira RF, Kinouchi O: Physics of psychophysics: Stevens and Weber-Fechner laws are transfer functions of excitable media. Phys Rev E 2002, 65-060901.

3. Publio R, Celis CC, Roque AC: Dynamic range of vertebrate retina ganglion cells: importance of active dendrites and coupling by electrical synapses. PLoS ONE 2012, 7:e48517.

4. Fohlmeister JF, Miller RF: Impulse encoding mechanisms of ganglion cells in the tiger salamander retina. J Neurophysiol 1997, 78:1935-1947.

doi:10.1186/1471-2202-15-S1-P59

Cite this article as: Celis et al:: Electrical coupling in the retina ganglion cell layer increases the dynamic range. BMC Neuroscience 2014

15(Suppl 1):P59.

\section{Submit your next manuscript to BioMed Central} and take full advantage of:

- Convenient online submission

- Thorough peer review

- No space constraints or color figure charges

- Immediate publication on acceptance

- Inclusion in PubMed, CAS, Scopus and Google Scholar

- Research which is freely available for redistribution

Submit your manuscript at www.biomedcentral.com/submit
Ciomed Central 